\title{
Islamic Education Teacher Communication Strategy in Increasing Students 'Learning Interest
}

\author{
Amiruddin Amiruddin ${ }^{1 *}$,Nurdin Nurdin ${ }^{2}$, and Moh. Ali ${ }^{3}$ \\ ${ }^{1}$ Islamic Education Department, Postgraduate, Institut Agama Islam Negeri Palu \\ 2 Islamic Education Department, Postgraduate, Institut Agama Islam Negeri Palu \\ ${ }^{3}$ Islamic Education Department, Postgraduate, Institut Agama Islam Negeri Palu
}

\begin{abstract}
This paper discusses the forms of academic communication of Islamic religious education teachers in Improving Student Learning Interest in Limua Dapurang Elementary School, Dapurang District, Pasangkayu Regency. This study used a case study approach. Data collection techniques in this study using observation, interviews and documentation. Data analysis techniques through data reduction analysis, data presentation and data verification that ends with checking the validity of the data with the source triangulation method. The results showed that the forms of Academic communication of Islamic education teachers in increasing the learning interest of the students regarding interpersonal communication which includes approaching, giving advice, exemplary, and reward. Second, group communication includes explaining the material gently, decisively and attractively, motivating and increasing the activeness of students and providing habituation. The results of increasing students' interest in learning caused students doing assignment diligently, hard studying, and increase student grades. The supporting factors include the teacher's ability to communicate, a willingness of students to receive advice and the support of class teachers. While the inhibiting factors are the level of understanding and response power of students and the lack of support from parents.
\end{abstract}

ARTICLE

INFORMATION

Keywords:

Islamic education, cummunication strategy, learning interest 


\section{Introduction}

One of the things that dominantly affects the interest of students is the ability of teachers to communicate. The success of the teacher in delivering the material really depends on the smooth interaction of the communication between the teacher and the students. The lack of fluency in communication has an impact on the messages conveyed by the teacher.

Through communication skills, the teacher can convey learning and increase students' interest in learning well because so far in the world of education, it often happens, the teacher always says the same words, without the teacher ignoring whether the child understands what he is conveying. in the learning process, sometimes even students have memorized what the teacher will say.

Roben said that communication is a behavioral activity or activity to convey messages or information about thoughts or feelings. ${ }^{1}$ In this case, communication is a means in the process of interacting to express an idea or ideas that a person has to another person or a group and is also a means of expressing the conditions experienced by that person to be shared with others. Communication also means a process of delivering messages by communicators (teachers) to communicants (students). The essence of communication is the process of declaration between people. What is stated is a person's thoughts or feelings

${ }^{1}$ Roben, Manusia Komunikasi, Komunikasi Manusia, (Jakarta: PT Kompas Media Nusantara, 2008), 20. towards others by using language as a means of channeling it. ${ }^{2}$

Educational activities in general and in the process of learning activities in particular, communication is one of the main factors that participate in determining the achievement of educational goals. In other words, it can be said that communication is a means or media to achieve educational goals. So to achieve teaching and learning interactions, it is necessary to have clear communication between teachers (communicators) and students (communicants). So that two efficient activities are integrated with achieving the goals of teaching and education where students can be successful in their learning tasks, and teachers can successfully teach and educate in accordance with the objectives to be achieved.

The teacher's learning communication ability can be seen in the interactions carried out by the teacher in the learning process, especially interactions that consciously set goals to change a person's behavior and actions. This interaction of educational value in the world of education is referred to as educational interaction. ${ }^{3}$

Teacher and student elements must be active in educational interactions, and it is impossible for educational interactions to occur if only one element is active. Active in the sense

2Onong Uchjana Effendy, M.A, Ilmu, Teori, Filsafat Komunikasi, (Bandung: PT. Citra Aditya Bakti, 2003), 28.

${ }^{3}$ Syaiful Bahri Djamarah, Guru Dan Anak Didik Dalam Interaksi Edukatif, (Jakarta:Rineka Cipta, 2005), 16. 
of attitude, mentality, and actions. In a teaching system with a process skills approach, students must be more active than teachers. The teacher only acts as a facilitator and motivator. 4

SD Inpres Limua Dapurang, Dapurang District, Pasangkayu Regency is one of the schools that is quite attractive. This is evident from the number of students in the school. However, there are many things that need to be considered, one of which is the lack of enthusiasm of students in receiving Islamic Religious Education lessons in schools, especially when the lessons are in the afternoon. This can be seen when the teacher explains the material that students are sleepy and joking with their classmates, so they lack concentration and do not pay attention to the lesson. As a result, the learning process did not run optimally. To overcome this, one of the things done by the Islamic Religious Education teacher at SD Inpres Limua Dapurang, Dapurang District, Pasangkayu Regency, is by communicating with students at the school.

Based on the above background, the researcher is interested in making a study entitled "Forms of Academic Communication for Islamic Religious Education teachers in increasing students' learning interest at SD Inpres

4 Kurniati, Kurniati, Nurdin, Nurdin, \& Nurasmawati, Nurasmawati. (2020). Improving Students' Cognitive and Affective Domains Students through Fostering Teacher Development International Journal of Contemporary Islamic Education, 2(2), 56-70.
Limua Dapurang, Dapurang District, Pasangkayu Regency."

\section{Literature review}

\subsection{Basic Concepts}

About

\section{Communication}

Etymologically, communication comes from Latin, namely cum, a preposition which means with or together with, and the word units a number which means one. The two words form the noun communio, which in English is called communion, which means togetherness, union, joint fellowship, association, or relationship. Because communicating requires effort and work, the word is made for a verb to communicate, which means sharing something with someone, exchanging, talking about something with people, telling something to someone, chatting, exchanging ideas, relating, and making friends. ${ }^{5}$ So, if two people are involved in communication, then the communication can be said to be successful if there is a similarity in meaning about what is being communicated. The similarity of the language used does not necessarily lead to the same meaning. 6

The general understanding of communication is the process of delivering a statement made by one person to another as a consequence of

5U. Saefullah, Manejemen Pendidikan Islam (cet. 1, Bandung: Pustaka Setia, 2012), 177.

${ }^{6}$ Nikmah Hadiati Salisah, Ilmu Komunikasi (Pasuruan: LunarMedia, 2012), 25

e-ISSN: $2715-4572$

p-ISSN: 2716-1439 
social relationships. ${ }^{7}$ Communication science is the study of the delivery of messages between humans. The object of communication is communication itself, namely the delivery of messages between humans. ${ }^{8}$

In addition to some definitions, according to the experts above, Roben said that communication is a behavioral activity or an activity to convey messages or information about thoughts or feelings.. ${ }^{9}$

In this case, communication is a means in the process of interacting to express an idea or ideas that a person has to another person or a group and is also a means of expressing the conditions experienced by that person to be shared with others. Meanwhile, Effendi said that communication is a similarity in the same sense of meaning. Suppose there are two people involved in communication, for example, in the form of a conversation. In that case, communication will occur or take place as long as there is a similarity in meaning about what is being said. ${ }^{10}$

Based on the above opinion, it is known that communication can occur between the two parties if the contents of the message to be conveyed by

${ }^{7}$ Onong Uchjana Effendy, Dinamika Komunikasi, (Bandung: PT. Remaja Rosda Karya, 2000), 5

${ }^{8}$ Nurani Soyomukti, Pengantar Ilmu Komunikasi, (Jogjakarta: Ar- Ruzz Media, 2010), 56

${ }^{9}$ Roben, Manusia Komunikasi, Komunikasi Manusia, (Jakarta: PT Kompas Media Nusantara, 2008), 20

10Onong Uchjana Effendi, Ilmu Komunikasi Teori dan Praktek (Cet. 20, Bandung: Rosdakarya, 2007), 9 someone are in accordance with what both parties want. This means that there is a match in understanding, thoughts, and desires between the two parties who will communicate.

Two parties or two people can only do communication; or in other words, communication is born because of the interaction made by at least two people. The two parties then share information in order to meet their respective needs. With the fulfillment of these needs, humans can maintain their survival. So that his life develops over time. It can be said that communication is an interaction or relationship that a person makes with others in order to meet their needs. ${ }^{11}$ Gode also argues that communication is a process that makes something that is originally owned by someone (one's monopoly) be owned by two or more people. ${ }^{12}$

Based on the above opinion, it can be concluded that communication is a form of interaction carried out by two or more people in order to convey messages in different ways so that they will get a response, the communication conveyed by the sender of the message to the recipient of this message can provide warnings, ideas, appeals, advice, questions, answers so that it will add information to the recipient of the message.

${ }^{11}$ Abdullah Munir, Membangun Komunikasi Efektif: Sebuah Upaya Mewujudkan Sekolah yang Membahagiakan (Yogyakarta: Mentari Pustaka, 2012), 4

12Vardiansyah, Filsafat Ilmu Komunikasi, (Jakarta: PT Indeks Gramedia, 2005), 25

e-ISSN: 2715-4572

p-ISSN: 2716-1439 


\subsection{Concept of Islamic Religious Education Teachers}

In-Law No. 14 of 2005 on teachers and lecturers, it can be understood that lecturers and teachers are basically the same; the difference is if teachers are in PAUD, primary education, and secondary education, while lecturers are in tertiary institutions.

As stated in articles 1 paragraph (1) and (2), teachers are professional educators with the main task of educating, teaching, guiding, directing, training, assessing, and evaluating students in early childhood education, formal education, and basic education. And secondary education. In contrast, lecturers are professional educators and scientists with the main task of transforming, developing, and disseminating science, technology, and art through education, research, and community service. ${ }^{13}$

According to Mahmud, the correct term for referring to teachers is $\mathrm{mu}$ 'allim. The original meaning of this word in Arabic is to mark. Psychologically, the teacher's job is to change student behavior. Basically, changing student behavior is giving a sign, that is, a sign of change. ${ }^{14}$

Syaiful Bahri revealed that teachers are all people that are authorized and responsible for guiding and fostering students, both individually

13 Undang-undang Guru dan Dosen No 14 tahun 2005 (Bandung: Fokusmedia, 2009), 2-3.

${ }^{14}$ Mahmud, Psikologi Pendidikan (Bandung: CV Pustaka Setia, 2010), 289 and classically, at school and outside of school. 15

Not much different, from the opinion above, a teacher has a very big role in shaping the character of students. ${ }^{16}$ A. Qodri interprets teachers as role models, caregivers, and advisors for the lives of students. The teacher's figure is often interpreted as digugu lan imitated, meaning that the example of the teacher is very important for students in value education. ${ }^{17}$

Based on the above understanding, it can be concluded that teachers are professional educators with the main task of educating, teaching, guiding, directing, training, assessing, and evaluating students in the path of formal education, basic education, and secondary education.

Meanwhile, Islamic Religious Education is standardized as the name of the activity of educating Islam. PAI as a subject should be called "Islam Religion" because what it teaches is Islam, not Islamic education. The name of its activity or efforts in educating Islam is known as Islamic religious education. The word "education" is in and follows every subject. Islamic

${ }^{15}$ Syaiful Bahri Djamarah, Guru dan Anak Didik dalam Interaksi Edukatif (Jakarta: PT Rineka Cipta, 2000), 31-32

${ }^{16}$ Rusli, R. (2020). The Role of Family in Preventing Social Conflict in Society From Islamic Perspectives. Hunafa: Jurnal Studia Islamika, 17(1), 108-122.

${ }^{17}$ A. Qodri A Azizy, Pendidikan (Agama) untuk Membangun Etika Sosial (Semarang: CV. Aneka Ilmu, 2003), 72

e-ISSN: $2715-4572$

p-ISSN: 2716-1439 
religious education is one part of Islamic education. ${ }^{18}$

According to Zakiah Daradjat, Islamic religious education is education through the teachings of the Islamic religion, educators guide and nurture students so that they can understand, live and practice the teachings of Islam as a whole, and make Islamic teachings a way of life to achieve safety and prosperity in the world and the afterlife. ${ }^{19}$

Another opinion says that Islamic Religious Education can be interpreted as a planned program in preparing students to know, understand, live, and believe in the teachings of Islam and follow guidance to respect adherents of other religions in relation to interreligious harmony to create unity and national unity. Wahab and others, interpret Islamic Religious Education Teachers as teachers who teach subjects of Akidah morals, Al-Qur'an and Hadith, fiqh or Islamic Cultural History (SKI) at Madrasah. ${ }^{20}, 21$

Meanwhile, etymologically, the meaning of Islamic Religious Education teachers is ustadz, mu'alim, murabbiy, murshid, mudarris, and mu'addib,

${ }^{18}$ Muhaimin, Pemikiran dan Aktualisasi Pengembangan Pendidikan Islam (Jakarta: Rajawali Press, 2012), 163

19Zakiah Daradjat, dkk, Ilmu Pendidikan Islam (Jakarta: Bumi Aksara, 1992), 86

${ }^{20}$ Wahab dkk, Kompetensi Guru Agama Tersertifikasi (Semarang: Robar Bersama, 2011), 63

21 Rusli, R. (2018). Fikih Ekologi dan Kearifan Tradisional: Tinjauan Terhadap Konsep Ihya' al-Mawat dan Hima. Hunafa: Jurnal Studia Islamika, 5(3), 287-298. which means that people provide knowledge with the aim of educating and developing students' morals to become people with good personalities. ${ }^{22}, 23$

The word ustadz usually implies that a teacher is required to be committed to professionalism in carrying out his duties, a person is said to be professional when he is attached to a high dedicative attitude towards his duties, an attitude of commitment to the quality of the process and work results, as well as an attitude of continuous improvement, which is always trying to improve and updating models, and strategies or how they work in accordance with the demands of the times, which are based on a high awareness that the task of educating is a task that prepares the next generation who will live in their time in the future.

Islamic Religious Education Teachers (GPAI) are educators who carry out guidance, teaching, and training activities consciously for their students to achieve the goals of Islamic religious education. Meanwhile, according to Abdul Majid and Dian Andayani, quoting from the 2002 PAI curriculum emphasized that Islamic religious education aims to foster and increase faith through the provision and

${ }^{22}$ Muhaimin, Pengembangan Kurikulum Pendidikan Agama Islam, (Jakarta: Raja Grafindo Persada, 2005), 44-49.

${ }^{23}$ Rusli, R., Hasyim, M. S., \& Nurdin, N. (2021). A New Islamic Knowledge Production And Fatwa Rulings: How Indonesia's Young Muslim Scholars Interact With Online Sources. Journal of Indonesian Islam, 14(2), 499-518.

e-ISSN: 2715-4572

p-ISSN: 2716-1439 
cultivation of knowledge, appreciation of the experiences and experiences of students about Islam so that they become Muslim humans who must develop in terms of faith. piety, nation, and state and to be able to continue at a higher level of education. ${ }^{24}$

From the various definitions above, it can be concluded that the definition of a teacher of Islamic Religious Education is a teacher who teaches the subjects of Akidah morals, Al-Qur'an and Hadith, figh or Islamic Cultural History (SKI) in schools/madrasas, their task is to shape students into human beings. Believe in and fear God Almighty, guide, educate and provide knowledge to students, are experts in the material and how to teach the material, and become role models for their students.

\subsection{Overview of Students' Learning Interests}

Etymologically, interest means attention, liking (inclination) of the heart to an activity. ${ }^{25}$ Meanwhile, in terminology, interest is attention which contains elements of feeling. Interest also determines an attitude that causes someone to be active in a job. In other words, interest can be the cause of an activity. ${ }^{26}$

\footnotetext{
${ }^{24}$ Abdul Majid, Pendidikan Agama Islam Berbasis Kompetensi Konsep dan Implementasi Kurikulum 2004 (Bandung: Remaja Rosdakarya, 2004), 130.

${ }^{25}$ WJS. Poerwodarminto, Kamus Umum Bahasa Indonesia (Jakarta: Balai Pustaka, 1984), 1134.

${ }^{26}$ Mahfud S., Pengantar Psikologi Pedidikan (Cet. IV; Surabaya: PT. Bina Ilmu, 2001), 92.
}

According to Slameto, interest is a feeling of preference and interest in something or activity without being asked. Interest is basically the acceptance of a relationship between oneself and something outside oneself. The stronger or closer the relationship, the greater the interest. ${ }^{27}$ Sardiman also stated that interest is a condition that occurs when one sees the temporary characteristics or meanings of a situation associated with one's own activities or needs. ${ }^{28}$

Interest is a feeling that arises from within a person or student to gravitate towards something he likes. Interest is important for every student to have because it involves a sense of interest in a field or subject taught by an educator to achieve satisfactory learning outcomes.

Dalyono, interest in learning can arise because of the attraction from outside and also comes from the heart. Great interest in something is a large asset which means to obtain objects or goals that are of interest. The emergence of interest in learning is due to various things, including a strong desire to raise dignity or get a good job and want to be happy and happy. Great interest in learning tends to produce high achievement; on the other hand, less interest in learning will result in low achievement. ${ }^{29}$

27 Slameto, Belajar dan Faktor-faktor yang Mempengaruhinya, Jakarta: Rineka Cipta, 2003, 180

${ }^{28}$ Sardiman, Guru dan Anak Didik dalam Interaksi Edukatif(Jakarta: Rineka Cipta, 2000), 224.

${ }^{29}$ Dalyono, Psikologi Pendidikan, (Jakarta: Rineka Cipta, 2001), 56

e-ISSN: $2715-4572$

p-ISSN: 2716-1439 
Based on the explanation from the experts above, it can be concluded that interest is a person's tendency to a favorite object or activity accompanied by a feeling of pleasure, attention, and activeness in doing.

Whereas learning is a business process carried out by a person to obtain a whole new change in behavior as a result of his own experience in interaction with his environment. ${ }^{30}$ According to Fathurrohman, learning is an activity that causes a change in behavior that is relatively constant, and that change is carried out through a deliberate activity or effort. ${ }^{31}$

According to Hilgard regarding learning, that:

Learning is a process of change through activities or training procedures in the laboratory or a natural environment. Learning is not just gathering knowledge, but learning is a mental process that occurs within a person, causing changes in behavior. ${ }^{32}$

Based on the understanding of learning above, understanding can be linked to learning as a tool for activities in order to gain knowledge, understanding, recognition, experience, observation, reading, listening, follow instructions, prowess, and intelligence.

\footnotetext{
${ }^{30}$ Slameto, Belajar dan Faktor-faktor yang Mempengaruhinya (Cet. VI; Jakarta : Rineka Cipta, 2013), 2.

${ }^{31}$ Muhammad Fathurrohman dan Sulistyorini, Belajar dan Pembelajaran (Yogyakarta: Teras, 2012), 174.

${ }^{32}$ Wina Sanjaya. Strategi pembelajaran Berorientasi Standar Proses Pendidikan (Jakarta: Prenada Media Group, 2010), 112.
}

Interest in learning is a psychological aspect of a person that shows itself in several symptoms, such as; passion, desire, and feelings of liking to carry out the process of behavior change through various activities, which include seeking knowledge and experience. In other words, interest in learning is attention, liking, someone's (students') interest in learning which is shown through enthusiasm, participation, and activeness in learning study.

\section{Methodology}

This study uses a qualitative approach with the object of research is a high school in Palu. In this study, the writer took one of the high schools to be the case.

Use qualitative methods in this study with several considerations. First, adjusting qualitative methods is easier when dealing with multiple realities. Second, it can directly present the nature of the relationship between researchers and informants ${ }^{33}$. Third, this method is more sensitive and adaptable to the many sharpening of the common direction and the patterns of values encountered. ${ }^{34}$

${ }^{33}$. Nurdin, Nurdin, Stockdale, Rosemary, \& Scheepers, Helana. (2014a). Coordination and Cooperation in E-Government: An Indonesian Local E-Government Case The Electronic Journal of Information Systems in developing Countries, 61(3), 1-21.

${ }^{34}$ Nurdin, Nurdin. (2018). Institutional Arrangements in E-Government Implementation and Use: A Case Study From Indonesian Local Government. International Journal of Electronic Government Research (IJEGR), 14(2), 44-63. doi: 10.4018/ijegr.2018040104

e-ISSN: 2715-4572

p-ISSN: 2716-1439 
Data were collected using observation techniques, in-depth interviews with the school principla and teachers from the school, and from shared written documents. ${ }^{35}$ While the data analysis is done using reduction and verification techniques with various data sources. ${ }^{36}$ The reduced data is then analyzed by claiming to the theoretical concepts used in this study.

\section{Result and Discussion}

\subsection{Forms of Academic Communication for Teachers of Islamic Religious Education}

Learning activities are a process of transforming educational messages in the form of learning materials from learning sources to learners. In learning, there is a communication process to convey messages from educators to students with the aim that messages can be received well and have an effect on understanding and changes in student behavior. ${ }^{37}$ This is realized to increase

${ }^{35}$.Nurdin, Nurdin, Stockdale, Rosemary, \& Scheepers, Helana. (2014b, 6-9 Jan. 2014). The Role of Social Actors in the Sustainability of EGovernment Implementation and Use: Experience from Indonesian Regencies. Paper presented at the System Sciences (HICSS), 2014 47th Hawaii International Conference on System Science.

36 Nurdin, Nurdin, \& Aratusa, Zana Chobita. (2020). Benchmarking level interactivity of Indonesia government university websites. TELKOMNIKA Telecommunication, Computing, Electronics and Control, 18(2), 853-859.

37 Evita, E., Syahid, A., \& Nurdin, N. (2019). Understanding Students' Learning Outcomes Differences Through the Application of the Market Place Activity Type of Cooperative Learning Model and the Application of Conventional Learning Models International human resources, which cannot be separated from improving the quality of learning. The quality of learning is influenced by the learning process, which depends on the effectiveness of the communication process that occurs in the learning. The following paerticipant said as follows:

"In my opinion, one form of academic communication carried out by the Islamic Religious Education teacher at SD Inpres Limua Dapurang, Dapurang District, Pasangkayu Regency is in the form of interactive communication when the learning process takes place in the classroom, which is done to attract student responses to be more active in the learning process. This can also prevent boredom of students and can increase students' interest in learning." 38

Students' learning interest is the main factor that determines the degree of student activeness in learning because interest is a relatively sedentary trait in a person, including in students. With the interest of a student will tend to do something that is of interest to him. Suppose it is drawn in the context of learning. In that case, the student's interest in learning will create a learning process that is conducive and reciprocal,

Journal of Contemporary Islamic Education, 1(1), 6785.

38 Patmawati, Kepala Sekolah "Wawancara" di kantor SD Inpres Limua Dapurang Kecamatan Dapurang Kabupaten Pasangkayu pada tanggal 13 Mei 2019

e-ISSN: 2715-4572

p-ISSN: 2716-1439 
meaning that all learning activities go as expected. There is feedback from students to what is conveyed by a teacher. On the other hand, if the students' interest in learning is lacking, problems will be found in the learning process, resulting in not optimal learning objectives.

The Principal of the Inpres Limua Dapurang Elementary School, Dapurang District, Pasangkayu Regency said that:

"Students' interest in learning at SD Inpres Limua Dapurang, Dapurang District, Pasangkayu Regency is quite good. This can be seen from the enthusiastic attitude of students in following the learning process. Students are happy to follow the direction of a teacher, happy to do the assignment given so that a learning process is created in accordance with what the teacher wants from each subject." 39

Based on the above statement, it can be seen that a student who has an interest in learning, especially the subject of Islamic Religious Education, will happily and happily participate in learning activities without coercion from either the teacher or the people around them.

To maintain and increase students' interest in learning in schools, one of which is that teachers must be able to create effective academic communication. Teachers are required to

\footnotetext{
39Patmawati, Kepala Sekolah "Wawancara" di kantor SD Inpres Limua Dapurang Kecamatan Dapurang Kabupaten Pasangkayu pada tanggal 13 Mei 2019
}

play a role and be responsible, so that teachers must have good communication skills. Once the teacher uses the importance of communication in the teaching and learning process for the student, the teacher must realize that a teacher is actually carrying out communication activities in carrying out learning activities. The communication carried out is in the form of academic communication. Therefore, teachers need to always choose and use words that are good and in accordance with the experiences of students.

The results of observations and interviews of researchers with informants show that the academic communication of Islamic Religious Education teachers is absolutely done at SD Inpres Limua Dapurang, Dapurang District, Pasangkayu Regency, the forms of communication are described as follows:

1. Interpersonal communication

Interpersonal communication or commonly known as interpersonal communication, is a communication that is applied in order to create emotional closeness in this study, namely between a teacher and students. According to the results of observations, interviews and strengthened from the distribution of questionnaires in grade 4 and grade 5 about students' interest in learning that has been carried out by researchers at SD Inpres Limua Dapurang, Dapurang District, Pasangkayu Regency. Interpersonal communication can increase students' interest in learning. The communication is carried out both verbally and non-verbally to students. 
The author describes the communication as follows:

a. Approachment

The approach taken by Islamic Religious Education teachers is in the form of an individual approach. This approach is intended to create emotional closeness between teachers and students. When students feel comfortable being next to their teacher, the students' happy feelings in following the learning will be created. This, of course, will increase students' interest in learning in the learning process.

Based on the results of the interview above, it is known that giving treatment to students at the elementary school level must be with an intense approach, must be able to ingratiate themselves with these students even though students have committed an offense but still treat it in a good way. When this is done, students will be happy to follow the learning process without coercion so that it will increase students' interest in learning.

b. Giving advises

In order to make students aware of the need for Islamic Religious Education subjects, teachers must always provide teachings or suggestions in the form of advice to students about the benefits or objectives of the Islamic Religious Education subject itself as said by the following participant:

Advising students, namely by explaining learning objectives. So we as teachers must be able to explain and provide understanding to students about the importance of learning Islamic Religious Education both at school and at home. Even though students today have tended to be happy to follow Islamic Religious Education lessons compared to exact lessons, advice after advice must still be carried out. 40

Based on the results of the interview, giving advice is important to do with that advice students will always understand and understand what they have to do after learning Islamic Religious Education is carried out, meaning that the learning process does not just stop at that time, but there is a follow-up in the form of an application. Students in daily activities.

c. Modeling attitude

Teachers have an important role in the modeling process. The attitudes and behavior of teachers have tremendous implications for their students. Teacher personality has a direct and cumulative influence on student behavior. Teacher behavior in the learning process is able to influence students' interest in learning. This means that if the personality displayed by the teacher is good in speech, attitudes and behavior will bring out the students' interest in the lesson. A participant said that:

The form of academic communication that I do, of course, must be a teacher figure who can be used as an example for students, both in terms of attitude/behavior and in terms of speaking. Many nowadays, a teacher communicates

${ }^{40} \mathrm{G}$. Ayu Yuni, Guru Kelas 5 "Wawancara" di kantor SD Inpres Limua Dapurang Kecamatan Dapurang Kabupaten Pasangkayu pada tanggal 21 Mei 2019

e-ISSN: 2715-4572

p-ISSN: 2716-1439 
with students by showing arrogance, saying words that are inappropriate for a teacher to say. ${ }^{41}$

Based on the results of the interview above, it can be concluded that one of the things that raise the interest of students in Islamic Religious Education lessons is the figure of the Islamic Religious Education teacher himself in terms of providing an example for these students about speaking, behaving and behaving. A teacher must be able to instill in the hearts of students about figures that should be used as examples in behavior.

\section{d. Giving Reward}

Giving rewards is a form of strengthening students when students ask questions or are able to answer questions and do a favor. In addition, the provision of rewards is also carried out to prevent and overcome the nonenthusiastic attitude of students in following the learning process. This is in accordance with the statement of a participant as follows::

If students succeed in answering the questions given the uplouse, in this way the students will feel more appreciated so that they will be motivated to return to enthusiasm in learning if they are excited, their interest in learning will increase, this form of communication must be maintained. ${ }^{42}$

\footnotetext{
${ }^{41}$ Ibid

${ }^{42}$ Mariani, Guru Pendidikan Agama Islam "Wawancara" di kantor SD Inpres Limua Dapurang Kecamatan Dapurang Kabupaten Pasangkayu pada tanggal 13 Mei 2019
}

Based on the results of the interview, it is known that giving rewards is essentially very supportive of students in increasing their interest in learning. With this reward, students will feel that they have received reinforcement and are appreciated for the good they do so that students will be motivated again to increase their interest in learning.

\section{Group Communication}

The communication carried out by Islamic Religious Education teachers to increase the learning interest of students at SD Inpres Limua Dapurang, Dapurang District, Pasangkayu Regency, is through group communication. In this study, group communication is communication carried out by giving messages to students in groups in the classroom, usually during the learning process. And also a description of the process of learning. Therefore, what is done by the teacher includes:

Things that usually make students lazy to follow the learning process because of saturation and dislike the lesson, the teacher delivers material in a monotonous way without presenting interesting things in between learning, sometimes also the attitude of an emotional teacher in dealing with problems that occur to participants students make students not interested in following the learning process. A participant said as follows:

"In addition to individual communication, communication is also carried out in groups. What I do is, of course, make an e-ISSN: 2715-4572 p-ISSN: 2716-1439 
interesting learning process. The learning material is not only focused on the books that have been provided, but a teacher must be able to relate teaching materials to situations experienced by students daily.

In the learning process, a teacher must be able to attract the attention of students, one of which is by conveying interesting things related to learning materials by linking them to the experiences of students or with examples that are developing in the community such as observations of students in class 5 regarding the fasting of Ramadhan, from the observations of the researcher, the researcher sees that the Islamic Religious Education teacher explains the material about fasting by giving examples of the habits of people who fast, especially the habits of children who often lie, pretend to perform ablution but carefully swallow their ablutions Another example, here shows the enthusiastic attitude of students in responding to messages from their teachers. This needs to be done because participants will not feel bored and provoked actively by the teacher's form of communication.

In addition, the teacher must also emphasize words or sentences that are necessary and must be done by students as said a participant:

"Assertiveness is important for a teacher because students will understand what to do and what to stay away from. If this is not good, then the teacher must give emphasis to the sentence such as being lazy, especially in the fasting month it is not good, the delivery is by increasing the intonation of the sentence." 43

Based on the results of interviews and observations, it can be seen that, in communicating with students, the most important thing is that the message can arrive and be accepted by students, for that, speech in conveying messages must be considered starting from presenting interesting content to emphasizing something that these learners must do.

Learning in the classroom is something that needs to be considered in every educational institution. Teachers are always required to be able to create a teaching and learning atmosphere that will have a positive impact in achieving optimal learning outcomes. Teachers must be able to teach appropriately, effectively, and efficiently to help improve learning activities. Then the thing that should not be forgotten is that the teacher must be able to motivate students in the learning process.

Motivation, both intrinsic and extrinsic, is a factor of the success of students in learning, and here the teacher is the main and important actor in providing enthusiasm and motivation to students. Providing motivation to students takes time and effort so that

\footnotetext{
${ }^{43}$ Siti Siti fatimah, Guru Kelas 4 "Wawancara" di kantor SD Inpres Limua Dapurang Kecamatan Dapurang Kabupaten Pasangkayu pada tanggal 21 Mei 2019
}

e-ISSN: 2715-4572

p-ISSN: 2716-1439 
their enthusiasm regarding learning increases. Another participant said:

In increasing students' interest in learning at SD Inpres Limua Dapurang, Dapurang District, Pasangkayu Regency, one of the things I can do is to provide motivation to students. Motivation is in the form of encouragement to participate in the ongoing learning process. Sometimes, this is done at the beginning of the learning process by telling characters who have been victorious because of their enthusiasm for learning and their benefits when seriously taking lessons. So that students will feel enthusiastic in following the process. ${ }^{4}$

Based on the interview results, it can be seen that to increase students' interest in learning, what a teacher can do is to always motivate students by telling someone's inspirational stories and the benefits obtained when serious in learning. ${ }^{45}$ In addition to providing motivation to students, what Islamic Religious Education teachers do is to make the learning process active.

Habit is one of the things done by Islamic Religious Education teachers to foster the curious attitude of students towards the material being taught. The habituation process is carried out by providing exercises to be done by students. With these exercises, students

44 Ibid.

${ }^{45}$ Rusli, R. (2014c). Teaching Usul al-Fiqh: A Multicultural Education Model. Al-Tahrir: Jurnal Pemikiran Islam, 14(2), 447-464. will get used to thinking critically and creatively.

To generate more curiosity of students by familiarizing students to do exercises on their worksheets and familiarize them to think and find new things related to the material presented. 46

Based on the results of the interview above, it is known that by getting students accustomed to thinking about the material given or in terms of completing tasks, these students will be accustomed to growing their curiosity about the material of Islamic Religious Education because they have been trained to think critically so that when there is new things that come to their minds will bring out more desire in them.

\subsection{Results of Increasing Student Interest in Learning}

After conducting interviews related to forms of academic communication for Islamic Religious Education teachers in increasing student interest in learning at SDN Inpres Limua Dapurang, Dapurang District, Pasangkayu District. It is also necessary to know the results of the increase in student interest in learning which was obtained from the results of interviews and teacher observations to participants. Students. It is known that this increase can be seen from a statement below:

"The form of increasing interest in learning from participants can be seen from various aspects, such as being diligent in going to school,

46 Ibid

e-ISSN: 2715-4572

p-ISSN: 2716-1439 
being diligent in doing assignments, being diligent in studying, and increasing the value of students." 47

Based on the results of the interview, it can be seen that the increase in student interest in learning can be seen from students diligently going to school, students diligently working on given assignments, diligently studying at home to increasing student learning scores. The results of the increase in student interest in learning are described as follows:

1. Diligently attend school

Diligently going to school is something that is sometimes very difficult for students to do, because they have to get up as early as possible to prepare themselves so that they can come to school on time, especially if the student likes the lesson or the teacher who teaches at the school.

Based on the results of the interview, it can be seen that students really like Islamic Religious Education lessons with various opinions such as good teacher factors and the material from the Islamic Religious Education lesson itself. With this interest, students become diligent in going to school, especially during Islamic Religious Education lessons. This can be seen by researchers from the results of class attendance observations of students in grade 4 and grade 5 at SD Inpres Limua Dapurang, Dapurang District,

${ }^{47}$ Mariani, Guru Pendidikan Agama Islam "Wawancara" di kantor SD Inpres Limua Dapurang Kecamatan Dapurang Kabupaten Pasangkayu pada tanggal 13 Mei 2019
Pasangkayu Regency. From the results of these observations, it can be seen that the increase in students entering school is more significant in the absence of alpha students in the class even though sometimes there are still good permits because of urgent matters or permission due to the condition of the body that does not allow students to enter school.

\section{Diligently doing assignments}

Doing assignments is something that is required of students, both tasks that must be done at school and tasks that must be done at home. The level of diligence in doing assignments can be seen from work on student worksheets that they always fill out if given orders to do it, sometimes they do it together or individually, do it at home or at school depending on the direction of the Islamic Religious Education teacher.

3. Study Diligently

Learning is not only done by students in the learning process in the classroom, but students also do at home. This can be seen from the observations of researchers in grades 4 and 5 at SD Inpres Limua Dapurang, Dapurang District, Pasangkayu Regency. When the learning process takes place, the teacher does not forget to ask students about the readiness of students to follow the learning process, including reading the subject matter at home. Hearing this question, many students claimed to have read some of the material that had been taught or was just doing the assignment given.

Based on the results of the interview, it can be concluded that with Islamic Religious Education teachers

e-ISSN: 2715-4572

p-ISSN: 2716-1439 
implementing academic communication it will be able to increase the learning interest of these students and not only interested in participating in class learning but also diligently studying at home and can apply the subject matter that has been given in life daily.

4. The value of students increases

Efforts to improve student learning outcomes are not only due to the teacher's factors but also from within the students themselves. The forms of communication carried out by the Islamic Religious Education teacher are in the form of interpersonal communication, namely Approaching students during the chase process, giving advice on things that should be done or things that should be done or should not be done by students, provide a good example so that students feel comfortable when the learning process takes place in the classroom and giving rewards to foster motivation of students to be more enthusiastic during the learning process.

In addition to interpersonal communication, communication is also carried out through group communication, namely by delivering learning materials using good communication so that students are more enthusiastic about receiving lessons so that they can foster student interest in learning both in the aspect of being diligent in going to school, diligently working on assignments, being diligent. Study so that the result can be satisfactory. This can be seen from the increases in the results of daily tests of students in schools that are listed in the teacher grade book in schools.

\section{Conclusion}

Based on the results of the discussion that has been stated above, the authors conclude that the forms of communication of Islamic Religious Education Teachers in increasing students' interest in learning at SD Inpres Limua Dapurang, Dapurang District, Pasangkayu Regency, namely, first, interpersonal communication, namely approaching, giving advice, exemplary and rewarding. Second, group communication, namely explaining the material gently, firmly, and attractively, providing motivation and increasing student activity, and providing habituation. The results of increasing students' interest in learning at SD Inpres Limua Dapurang, Dapurang District, Pasangkayu Regency were diligent in going to school, diligent in doing assignments, diligent learning, and increased student scores.

\section{REFERENCES}

Abidin, Syahrul, Strategi Komunikasi Guru dalam Meningkatkan Prestasi Belajar, Jurnal Ihyaul Arabiyah, Vomule 3, nomor 2, tahun 2017.

Ahmad, Abu, Metodik Khusus Pendidikan Agama, Bandung: Amrico, 1986.

Alim, Muhammad, Pendidikan Agama Islam Upaya Pembentukan Pemikiran dan Kepribadian Muslim, Bandung: PT Remaja Rosdakarya, 2006.

Asmani, Jamal Ma'ruf, Tips menjadi Guru Inspiratif, Kreatif, dan Inovatif, cet. Ke- 2, Jogjakarta: Diva Press, 2009

e-ISSN: 2715-4572

p-ISSN: 2716-1439 
Arikunto, Suharsimi, Manajemen Penelitian, Jakarta: Rineka Cipta, 2005.

Arikunto, Suharsimi, Prosedur Penelitian Suatu Pendekatan Praktek, Jakarta: Rineka Cipta, 2006.

Arni, Muhammad, Komunikasi Organisasi, cet. ke- 4., Jakarta: Bumi Aksara, 2001.

Azzet, Akhmad Muhamimin, Urgensi Pendidikan Karakter di Indonesia, Jogjakarta: Ar-Ruzz Media, 2011.

Azizy, Qodri A, Pendidikan (Agama) untuk Membangun Etika Sosial, Semarang: CV. Aneka Ilmu, 2003.

Bungin, Burhan, Analisis Data Penelitian Kualitatif, Jakarta: Raja Grafindo, 2005.

Cangara, Hafied, Pengantar Ilmu Komunikasi, Cet. Ke-4., Jakarta: PT. Grafindo Persada, 2003.

Cangara, Hafied , Pengantar Ilmu Komunikasi, Cet.2, Jakarta: PT Raja Grafindo, 2012.

D.Gunarsa, Singgih, Psikologi Perawatan, Cet. IX; Jakarta: BPK Gunung Mulia, 2004.

Dalyono, Psikologi Pendidikan, Jakarta: Rineka Cipta, 2001.

Departemen Agama RI, Al-Qur'an dan Tafsirnya, Jakarta: Lentera Abadi, 2010.

Depag, Pedoman Pelaksanaan Kurikulum Sekolah Menengah, (Jakarta: Direktorat Jenderal kelembagaan Agama Islam, 2005.

Departemen Agama, Undang-Undang dan Peraturan Pemerintah RI tentang Pendidikan, Jakarta:Dirjen Pendidikan Islam, 2006.
Djamarah, Syaiful Bahri, Guru Dan Anak Didik Dalam Interaksi Edukatif, Jakarta: Rineka Cipta, 2005.

Djamarah, Syaiful Bahri , Pola Asuh Orang Tua dan Komunikasi dalam Keluarga, Jakarta: Rineka Cipta, 2014.

Daradjat, Zakiah, dkk, Ilmu Pendidikan Islam, Jakarta: Bumi Aksara, 1992.

Dimyati dan Mudjiono, Belajar dan Pembelajaran, cet ke- 1; Jakarta: PT. Rineka Cipta, 1999.

Effendi, Onong Uchjana, Dimensi-dimensi Komunikasi, Cet. Ke-4., Bandung: PT. Remaja Rosdakarya, 2004.

Effendi, Onong Uchjana , Ilmu Komunikasi teori dan praktek, Bandung: PT.Remaja Rosdakarya. 2006.

Effendi, Onong Uchjana, Ilmu, teori dan filsafat komunikasi, Bandung: Citra Aditya, 2003.

Evita, E., Syahid, A., \& Nurdin, N. (2019). Understanding Students' Learning Outcomes Differences Through the Application of the Market Place Activity Type of Cooperative Learning Model and the Application of Conventional Learning Models International Journal of Contemporary Islamic Education, 1(1), 67-85.

Fajar, Marhaeni, Ilmu Komunikasi: Teori $\mathcal{E}$ Praktik, Jakarta: Graha Ilmu, 2009.

Fathurrohman, Muhammad dan Sulistyorini, Belajar dan Pembelajaran, Yogyakarta: Teras, 2012.

Fiske, John, Pengantar Ilmu Komunikasi, ter. Hapsari Dwiningtyas, Jakarta: Rajawali Pers, 2012. 
Hadi, Sutrisno, Metodologi Research Jilid I, Cet. XXIX; Yogyakarta: Andi Yogyakarta, 1997.

Hamzah, Profesi Kependidikan, Jakarta: Bumi Aksara, 2007.

Hamzah. Profesi Kependidikan, Problema, Solusi dan Reformasi Pendidikan, Jakarta: Bumi Aksara, 2007.

Hardjana, Komunikasi Intrapersonal dan Interpersonal, Yogyakarta: Kanisius, 2003.

Hidayat, Dasrun, Komunikasi Antar Pribadi dan Medianya, Yogyakarta: Graha Ilmu, 2009.

Imran, Ali, Belajar dan Pembelajaran, Cet, ke-3, Jakarta: PT Dunia Pustaka Jaya, 2006.

Idi, Abdullah, Pengembangan Kurikulum Teori dan Praktik,, Yogyakarta: ArRuzzMedia, 2007.

Junita, Ike, Prinsip Komunikasi Efektif Untuk meningkatkan Minat Belajar Anak, Bandung: Sambiosa Rakatama Media, 2008.

Kunandar, Guru Profesional: Implementasi Kurikulum Tingkat Satuan Pendidikan

(KTSP) dan Sukses dalam Sertifikasi Guru, Jakarta: Rajawali Pers, 2009.

Kurniati, Kurniati, Nurdin, Nurdin, \& Nurasmawati, Nurasmawati. (2020). Improving Students' Cognitive and Affective Domains Students through Fostering Teacher Development International Journal of Contemporary Islamic Education, 2(2), 56-70.

Liliweri, Alo, Komunikasi Serba Ada Serba Makna, Jakarta: Kencana Prenada Media Group, 2011
Mahfud S., Pengantar Psikologi Pedidikan, Cet. 4, Surabaya: PT. Bina Ilmu, 2001.

Malik, Abdul Fungsi Komunikasi Antara Guru dan Siswa dalam Meningkatkan Kualitas Pendidikan (Studi Kasus Proses Belajar Mengajar pada SMP Negeri 3 Sindue), Jurnal Interaksi, Volume 3, Nomor 2, tahun 2014.

Mahmud, Psikologi Pendidikan, Bandung: CV Pustaka Setia, 2010.

Majid, Abdul, Pendidikan Agama Islam Berbasis Kompetensi Konsep dan Implementasi Kurikulum 2004, Bandung: Remaja Rosdakarya, 2004.

Majid, Abdul, Perencanaan Pembelajaran Mengembangkan Standar Kompetensi, Bandung: PT. Rosdakarya Offset, 2008.

Majid, Abdul, Perencanaan Pembelajaran Mengembangkan Standar Kompetensi, Bandung: PT. Rosdakarya Offset, 2008.

Milles, Matthew B., et.al, Qualitative Data Analisys, diterjemahkan oleh Tjetjep Rohendi Rohidi dengan judul Analisis data Kualitatif, buku sumber tentang Metode-metode Baru, Cet. I; Jakarta: UI-Pres, 1992.

Moleong, Lexy J. , Metodologi Penelitian Kualitatif, Cet. XIV; Bandung: Remaja Rosda Karya, 2001.

Muchith, M. Saekhan, Pembelajaran Kontekstual, cet.1, Semarang: Rasail Media Group,2008.

Mudyahardjo, Pengantar Pendidikan, Jakarta: PT.Raja Grafindo Persada, 2001. 
Muhaimin, Pemikiran dan Aktualisasi Pengembangan Pendidikan Islam, Jakarta: Rajawali Press, 2012.

Muhaimin, Pengembangan Kurikulum Pendidikan Agama Islam, Jakarta: Raja Grafindo Persada, 2005.

Mulyasa, E. Standar Kompetensi Sertifikasi Guru, Bandung, PT. Remaja Rosdakarya, 2007

Mulyana, Dedi, Metode Penelitian Kualitatif, Bandung: Remaja Rosdakarya, 2008.

Munir, Abdullah, Membangun Komunikasi Efektif: Sebuah Upaya Mewujudkan Sekolah yang Membahagiakan, Yogyakarta: Mentari Pustaka, 2012.

Nasution, Metodologi Research (Penelitian Ilmiah), Jakarta: Bumi Aksara, 2003.

Nasir, Sahilun A. Peranan Pendidikan Agama terhadap Pemecahan Problema Remaja, cet. Ke-2, Jakarta: Kalam Mulia, 2002

Nurdin, Nurdin, Stockdale, Rosemary, \& Scheepers, Helana. (2014a). Coordination and Cooperation in E-Government: An Indonesian Local E-Government Case The Electronic Journal of Information Systems in developing Countries, 61(3), 1-21.

Nurdin, Nurdin. (2018). Institutional Arrangements in E-Government Implementation and Use: A Case Study From Indonesian Local Government. International Journal of Electronic Government Research (IJEGR), 14(2), 44-63. doi: 10.4018/ijegr.2018040104

Nurdin, Nurdin, Stockdale, Rosemary, \& Scheepers, Helana. (2014b, 6-9 Jan.
2014). The Role of Social Actors in the Sustainability of E-Government Implementation and Use: Experience from Indonesian Regencies. Paper presented at the System Sciences (HICSS), 2014 47th Hawaii International Conference on System Science.

Nurdin, Nurdin, \& Aratusa, Zana Chobita. (2020). Benchmarking level interactivity of Indonesia government university websites. TELKOMNIKA Telecommunication, Computing, Electronics and Control, 18(2), 853-859.

Prawiradilaga, Dewi Salma, Kawasan Teknologi Pendidikan, Cet ke-1; Jakarta: Kencana Prenada Media Grup, 2012.

Rakhmat, Jalaluddin, Psikologi Komunikasi, Bandung: PT. Remaja Rosdakarya, 2009

Rahardjo, Fitri, dkk, Himpunan Lengkap Undang-Undang Sistem Pendidikan Nasional (Jogjakarta: Saufa, 2014.

Ramayulis, Metodologi PAI, Jakarta: Kalam Mulia, 2005.

Rusman, Model-model Pembelajaran Mengembangkan Profesional Guru, Jakarta:

Rajawali Pers, 2010.

Sa'ud, Udin Saefudin, Inovasi Pendidikan, cet ke-1; Bandung: AlfaBeta, 2008.

Sagala, Syaiful. Kemampuan Professional Guru Dan Tenaga Kependidikan. Bandung: Alfabeta, 2009.

Ricardo, Rini Intansari Meilani, Impak Minat Dan Motivasi Belajar Terhadap Hasil Belajar Siswa, Jurnal Pendidikan Manajemen Perkantoran, Vol.1_No.1 Juli 2017.

e-ISSN: 2715-4572

p-ISSN: 2716-1439 
Roben, Manusia Komunikasi, Komunikasi Manusia, Jakarta: PT Kompas Media Nusantara, 2008.

Roben, Manusia Komunikasi, Komunikasi Manusia, Jakarta: PT Kompas Media Nusantara, 2008.

Robert C. \& Stren J. Tailor, Kualitatif, Dasar-Dasar Penelitian, Usaha Nasional, 1993.

Roudhonah, Ilmu Komunikasi, Cet. Ke1.,Jakarta: Kerja Sama Lembaga Penelitian UIN Jakarta dan Jakarta Pers, 2007.

Rusli, R., Hasyim, M. S., \& Nurdin, N. (2021). A New Islamic Knowledge Production And Fatwa Rulings: How Indonesia's Young Muslim Scholars Interact With Online Sources. Journal of Indonesian Islam, 14(2), 499-518.

Rusli, R. (2020). The Role of Family in Preventing Social Conflict in Society From Islamic Perspectives. Hunafa: Jurnal Studia Islamika, 17(1), 108-122.

Rusli, R. (2018). Fikih Ekologi dan Kearifan Tradisional: Tinjauan Terhadap Konsep Ihya' al-Mawat dan Hima. Hunafa: Jurnal Studia Islamika, 5(3), 287-298.

Rusli, R. (2014c). Teaching Usul al-Fiqh: A Multicultural Education Model. Al-Tahrir: Jurnal Pemikiran Islam, 14(2), 447-464.

Saefullah, Manejemen Pendidikan Islam, cet. 1, Bandung: Pustaka Setia, 2012.

Salisah, Nikmah Hadiati, Ilmu Komunikasi, Pasuruan: LunarMedia, 2012.

Sanjaya, Wina. Strategi pembelajaran Berorientasi Standar Proses
Pendidikan, Jakarta: Prenada Media Group, 2010.

Sardiman, Guru dan Anak Didik dalam Interaksi Edukatif, Jakarta: Rineka Cipta, 2000.

Sardiman, Interaksi dan Aktivitas Belajar Mengajar, Jakarta: Rajawali Pers, 2004

Shaleh, Abdul Rachman, Pendidikan Agama \& Pembangunan Watak Bangsa

Jakarta: PT Raja Grafindo Persada, 2005.

Singer, Kurt, Membina Hasrat Belajar di Sekolah, (Terj. Bergman Sitorus), Cet. IV; Bandung: Remaja Rosda Karya, 2003.

Slameto, Belajar dan Faktor-faktor yang Mempengaruhinya, Cet. VI, Jakarta : Rineka Cipta, 2013.

Slameto, Belajar dan Faktor-faktor yang Mempengaruhinya, Jakarta: Rineka Cipta, 2003.

Soyomukti, Nurani, Pengantar Ilmu Komunikasi, Jogjakarta: Ar- Ruzz Media, 2010.

Sugiono, Metode Penelitian Pendidikan; Pendekatan Kualitatif, dan $R$ dan $D$ Bandung: Alfabeta, 2008.

Suardi, Edi, Pedagogik, Bandung: Angkasa OFFSET, 1979.

Sudjana, Nana Dasar-dasar Proses Belajar Mengajar, Bandung: Sinar Baru Algensindo,2005.

Sudjana, Nana, Dasar-dasar Proses Belajar Mengajar, Bandung: Sinar Baru Algensindo,2005

Suharto, Toto, Filsafat Pendidikan Islam, Yogyakarta: Ar-ruzz, 2006.

e-ISSN: 2715-4572

p-ISSN: 2716-1439 
Suryobroto, Proses Belajar Mengajar di Sekolah, Jakarta: PT Rineka Cipta, 1997

Sumantri, Mulyani, Perkembangan Peserta Didik, Jakarta, UT, 2007.

Surahmad, Winarno, Dasar dan Teknik Research Pengantar Metodologi Ilmiah, Bandung: Badan Penerbit IKIP Bandung, 1968.

Surya, Kapita Selekta Kependidikan SD, Jakarta: UT, 2001.

Tampubolon, D.P Mengembangkan Minat Membaca pada Anak, Cet. VI; Bandung: Angkasa, 2003..

Tanzeh, Ahmad, Metode Penelitian Praktis, Jakarta: Bina Ilmu, 2004.

Uhbiyati, Nur dan Ahmadi, Abu, Ilmu Pendidikan Islam I, Bandung: CV Pustaka Setia, 1998.

Umar, Husein, Metode Penelitian untuk Skripsi dan Tasir Bisnis,, Cet. IV ; Jakarta: PT. Raja Grafindo, 2000.

Uno, Hamzah B. dan Nina Lamatenggo, Teknologi Komunikasi dan Informasi Pembelajaran, cet ke-2; Jakarta: Bumi Aksara, 2011.

Vardiansyah, Filsafat Ilmu Komunikasi, Jakarta: PT Indeks Gramedia, 2005.

Wahab dkk, Kompetensi Guru Agama Tersertifikasi, Semarang: Robar Bersama, 2011.

Warsita, Bambang, Teknologi Pembelajaran, Jakarta: PT. Rineka Cipta, 2008.

Widjaja, Komunikasi dan Hubungan Masyarakat, Jakarta: PT. Bumi Aksara, 2002.

WJS. Poerwodarminto, Kamus Umum Bahasa Indonesia, Jakarta: Balai Pustaka, 1984. 